VOLUMINA JURASSICA, 2020, XVIII (1): 1-22

DOI: 10.7306/VJ.18.1

\title{
The Bajocian to Kimmeridgian (Middle to Upper Jurassic) ammonite succession at Sentralbanken High (core 7533/3-U-1), Barents Sea, and its stratigraphical and palaeobiogeographical significance
}

\author{
Andrzej WIERZBOWSKI ${ }^{1}$, Morten SMELROR ${ }^{2}$
}

Key words: Middle and Upper Jurassic, ammonites, Boreal and Subboreal provinces, correlation, palaeobiogeography.

\begin{abstract}
Ammonites recovered from Upper Bajocian to Upper Kimmeridgian strata in a core drilled at Sentralbanken High in the northern Barents Sea are described and chronostratigraphically interpreted. The lower part of the core comprises Upper Bajocian to Upper Callovian deposits of the Fuglen Formation with ammonites of the genus Cranocephalites near the base, and Longaeviceras in the upper part. The overlying Oxfordian to Kimmeridgian deposits of the Hekkingen Formation are thin and condensed. The Hekkingen Formation is dominated by Boreal cardioceratid ammonites (Cardioceras, Amoebites, Euprionoceras, Hoplocardioceras), with numerous Subboreal aulacostephanid ammonites (Rasenia, Zenostephanus) at two levels. The occurrences of Boreal and Subboreal ammonites are discussed in relation to the palaeogeography and fluctuations of ammonite faunas within the Boreal Realm during the Kimmeridgian with special attention to levels rich in Subboreal ammonites whose appearance has been controlled by tectonic and climatic factors. The uppermost part of the succession deposited during a time of maximum flooding in the Late Kimmeridgian is dominated by Boreal ammonites.
\end{abstract}

\section{INTRODUCTION}

Shallow stratigraphic drillings on the western Barents Shelf in the past four decades have provided key records of stratigraphic data. Shallow stratigraphic boreholes, generally with continuous cores, were drilled at various localities by SINTEF Petroleum Research (earlier IKU) between 1984 and 1990 and by the Norwegian Petroleum Directorate between 1990 and 2005 (Bugge et al., 1995, 2002; Smelror et al., 2001; Vigran et al., 2014). Ammonite faunas recovered in the cores have proved important tools for high-resolution stratigraphy of the Middle and Upper Jurassic sequences, and for regional correlations between offshore and onshore successions (Wierzbowski, Århus, 1990; Wierzbowski, Smelror, 1993; Wierzbowski et al., 2002).
The present paper concerns ammonites recovered in borehole 7533/3-U-1 drilled in 1990 at the Sentralbanken High in the northwestern part of the Barents Sea (Fig. 1). In addition to a high-resolution biostratigraphic breakdown of the cored succession, the recovered ammonite faunas are used for palaeobiogeographical interpretations. The studied core from the Sentralbanken High comes from a location between the previously investigated sections to the north on Spitsbergen, Kong Karls Land and Franz Josef Land, and to the south in the Nordkapp Basin and offshore Troms III and Nordland VII areas. Through most of the Middle and Upper Jurassic succession which has been studied, the recovered ammonites comprise Boreal Cardioceratidae faunas, but the incoming of Subboreal Aulacostephanidae ammonites at two Kimmeridgian intervals offers possibilities to gain an

\footnotetext{
${ }^{1}$ University of Warsaw, Faculty of Geology, Żwirki i Wigury 93, PL 02-089 Warszawa, Poland; andrzej.wierzbowski@uw.edu.pl.

${ }^{2}$ Geological Survey of Norway, Postboks 6315 Torgarden, NO-7491 Trondheim, Norway; morten.smelror@ngu.no.
} 


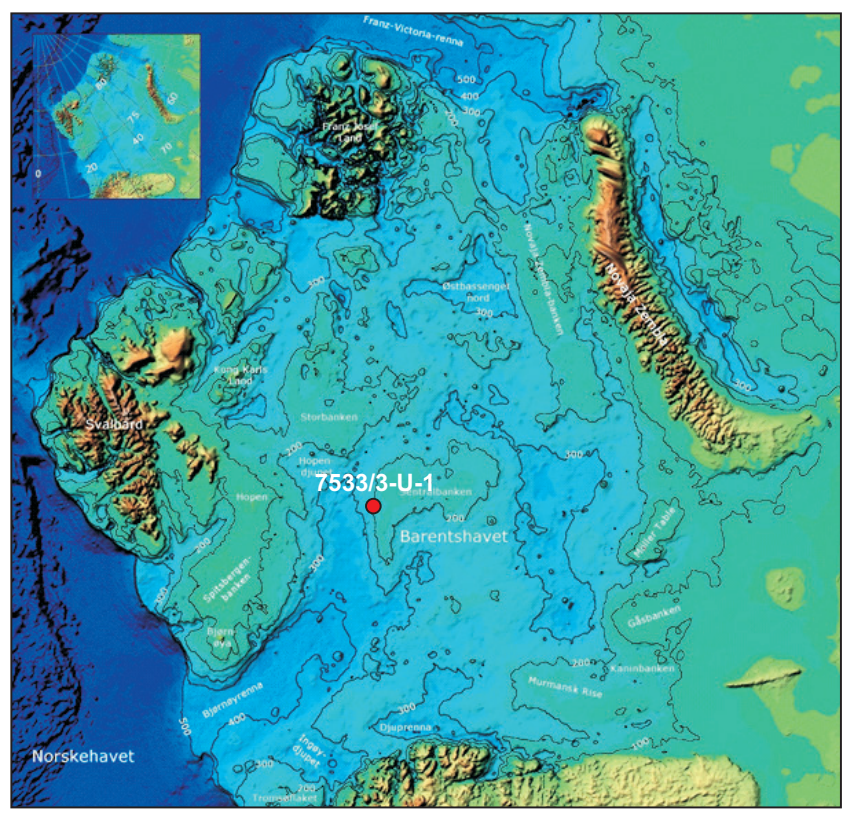

Fig. 1. Location map of borehole $7533 / 3-U-1$ at the Sentralbanken High, Barents Sea

insight into fluctuations in the marine connections between the Boreal and Subboreal provinces during the tectonicly active Late Jurassic time.

The ammonites are housed and catalogued in the collection of the Museum of the Geological Faculty of the Warsaw University (collection numbers: MWG UW ZI/98).

\section{CORE DESCRIPTION}

Borehole 7533/3-U-1 was drilled through $1.8 \mathrm{~m}$ of Quaternary surficial deposits and $118.75 \mathrm{~m}$ into Lower Cretaceous and Jurassic bedrocks. The borehole was fully cored, and the core divided into four lithological units (formations), of which the Cretaceous formations are not treated herein. Ammonites which were recovered from the two oldest formations of Middle and Late Jurassic ages, are described (Figs. 2, 3).

The oldest formation, covers the interval from TD at 120.55 up to $71.52 \mathrm{~m}$ and consists of dark grey shales and siltstones of Late Boreal Bajocian to Late Callovian (or even earliest Oxfordian) age. The sediments show planar lamination, and intervals with calcareous and sideritic nodules are found throughout the unit. Beds with bioturbation are common in the lower part of the unit, more scattered in the upper part. Belemnites and bivalves were recovered throughout the unit, along with ammonites. The unit was deposited in an open shelf environment and correlates to the Fuglen For- mation as defined further south in the Barents Sea (Worsley et al., 1988).

The overlying formation from 71.52 to $48.38 \mathrm{~m}$ comprises dark grey, organic rich, claystones of Early Oxfordian to Late Kimmeridgian age. Planar lamination is seen through the entire unit. Beds with bioturbation are found in the lower part of the unit (below $66 \mathrm{~m}$ ). Some belemnites and bivalves are found in the upper part. The unit belongs to the Hekkingen Formation and was deposited in a shelf environment, partly in a setting with restricted bottom-water circulation and anoxic conditions. The boundary with the overlying condensed carbonates of the Early Cretaceous Klippfisk Formation is marked by a stratigraphic break, where Volgian-Ryazanian strata are missing.

\section{AMMONITE STRATIGRAPHY}

The two oldest ammonites recovered from 117.24 and $115.67 \mathrm{~m}$ in the core belong to the genus Cranocephalites. The succession of the Cranocephalites-beds has been studied in detail in Jameson Land in East Greenland where a large number of successive faunal horizons were distinguished by Callomon et al. (2015). The specimens studied here are compared with the ammonites of that succession. Cranocephalites ammonites were also described from northern and north-eastern Siberia by Meledina (1973). However, these ammonites represent a less complete succession of species and the described specimens differ in their ornamentation from those from East Greenland (see Callomon et al., 2015) and the specimens presented herein.

The occurrence of Cranocephalites indistinctus at $117.24 \mathrm{~m}(\mathrm{Pl} .1: 1 \mathrm{a}-\mathrm{d})$ is indicative of the Indistinctus Zone, whereas younger Cranocephalites sp. at $115.67 \mathrm{~m}$ (Pl. 1: 2) may represent any stratigraphical level from the Indistinctus Zone up to the top of the Pompeckji Zone of the so-called Cranocephalites beds (Callomon et al., 2015). The ammonites from 117.24 to $115.67 \mathrm{~m}$ are indicative of the Boreal Upper Bajocian (Callomon, 2003).

Upwards in the core the ammonite fauna consists of two specimens found at 99.42 and $94.60 \mathrm{~m}$ assigned to Kepplerites and Pseudocadoceras, respectively.

The occurrence of the genus Kepplerites at $99.42 \mathrm{~m}$ indicates a correlation to the stratigraphical interval from the Boreal Middle Bathonian Cranocephaloide Zone and up to the end of the Lower Callovian (Callomon, 1975, 1985, 1993; see also Mitta et al., 2014). Cadoceratids such as the one from $94.60 \mathrm{~m}$, similar to Pseudocadoceras, are known to occur from the Boreal Variabilis Zone of the Boreal Upper Bathonian (but some forms transitional to older Arcticoceras occur already in the Cranocephaloide Zone; see Cal- 


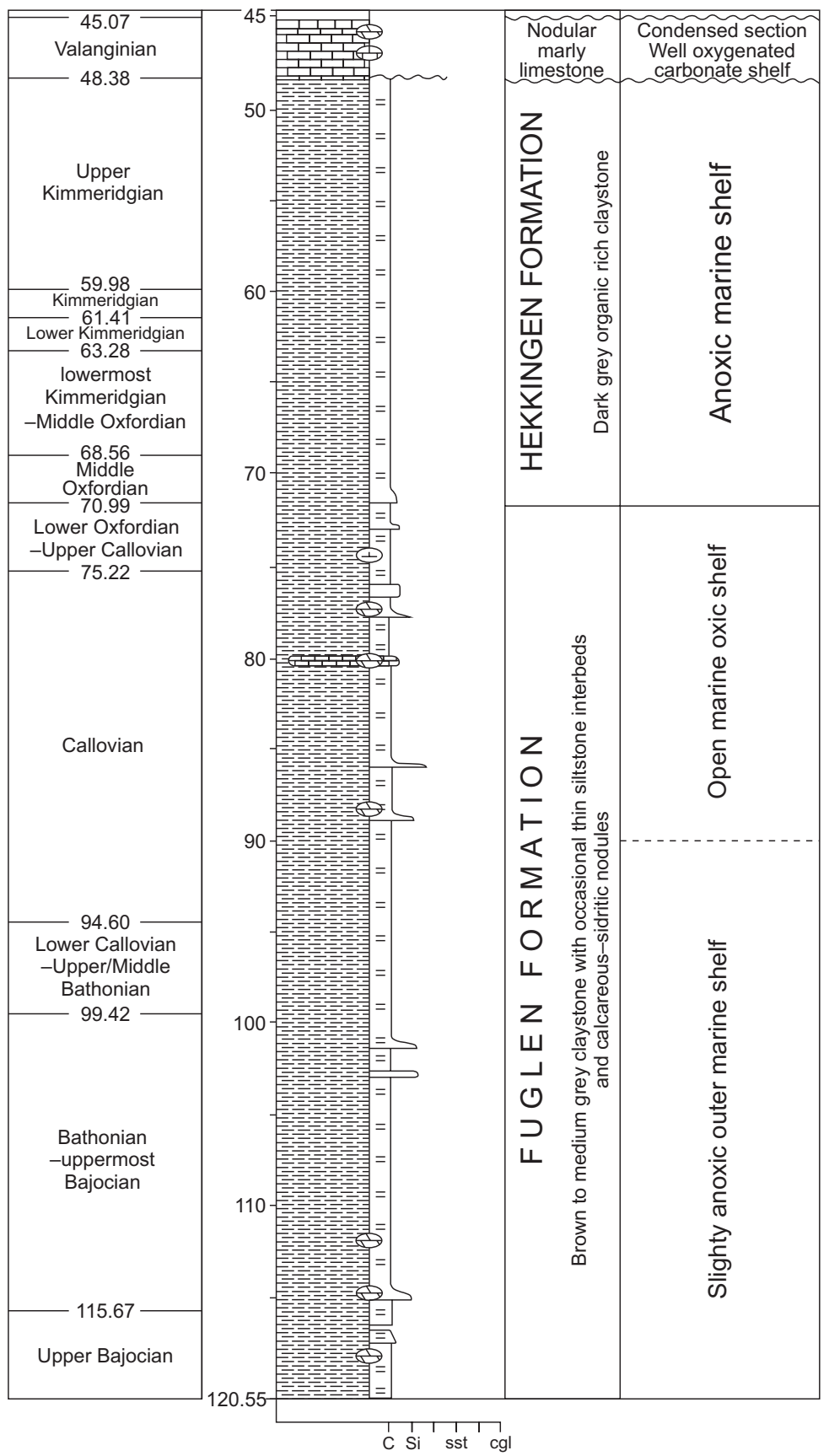

Fig. 2. Lithological log of core 7533/3-U-1 and its stratigraphical and sedimentological interpretation

lomon, 1985), and up to the Middle and even lowest Upper Callovian (Callomon, 1993; Meledina, 1977; Kopik, Wierzbowski, 1988). Taking into account, however, the fact that Pseudocadoceras occurs very near to Kepplerites in the core, as well as the fact that the directly younger ammonite at $75.22 \mathrm{~m}$ is indicative of the Upper Callovian (see below), the studied interval between 99.42 and $94.60 \mathrm{~m}$ possibly represents only a fragment of the Middle Bathonian-Lower Callovian succession (Fig. 2).

The ammonite from $75.22 \mathrm{~m}$ may be referred to the genus Longaeviceras, representing the L. placenta (Leckenby) - L. longaevum (Leckenby) species (Pl. 1: 3), and is indicative of the Athleta Zone of the Upper Callovian (see Kiselev, Rogov, 2018, and earlier papers cited therein). 


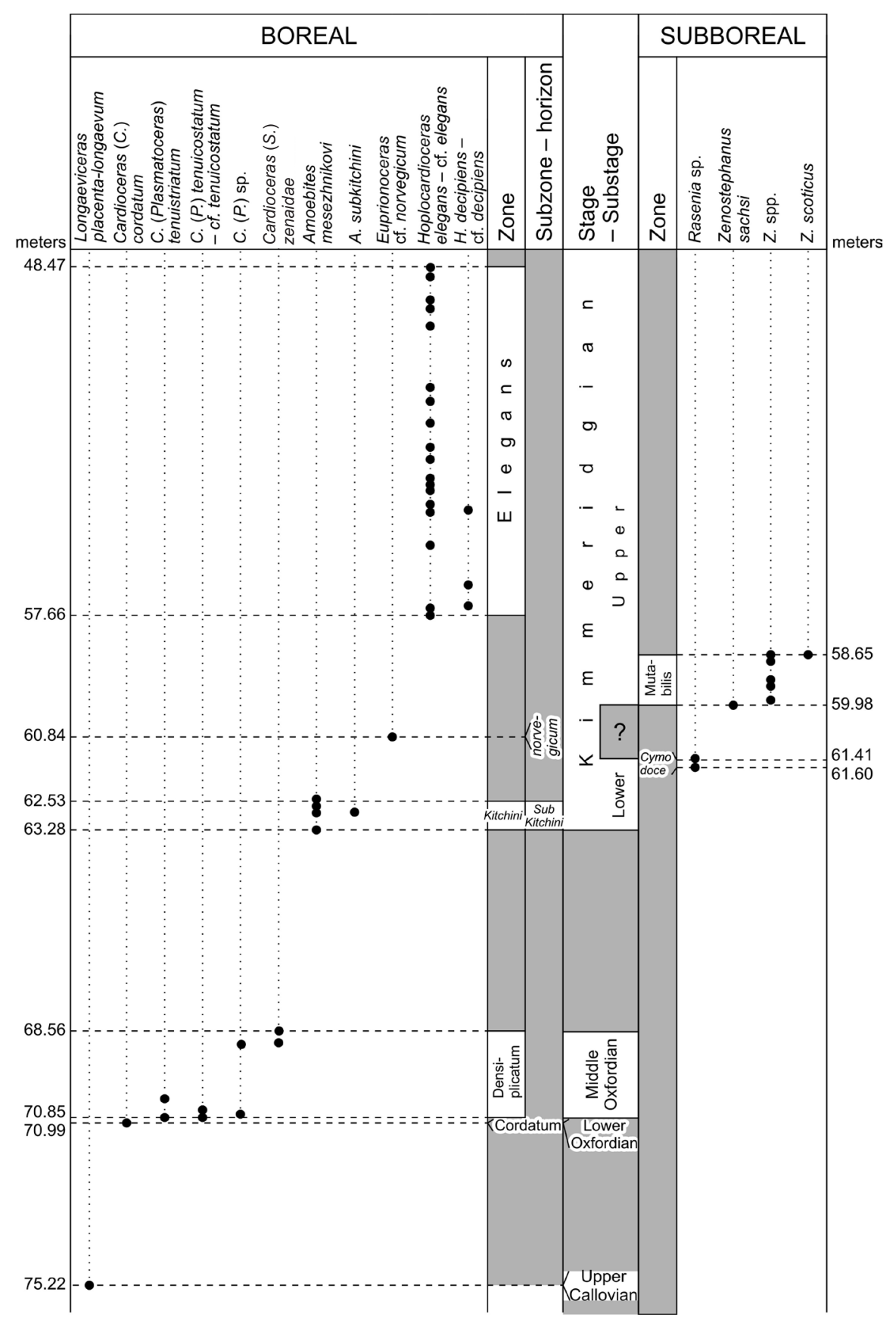

Fig. 3. Ammonite distribution and chronostratigraphical interpretation of the deposits from the Upper Callovian to the Upper Kimmeridgian in core $7533 / 3-\mathrm{U}-1$

The overlying younger ammonite faunas, composed entirely of representatives of the genus Cardioceras, are typical of the Oxfordian. The specimen found at $70.99 \mathrm{~m}$ is Cardioceras (Cardioceras) cordatum (Sowerby) (Pl. 1: 4). It indicates the upper part of the Cordatum Zone, i.e. the Cordatum Subzone, which represents the topmost part of the Lower Oxfordian (Arkell, 1941). In accordance with that, the boundary between the Callovian (as marked by occurrence of Longaeviceras) and the Oxfordian, has to be placed in a $4.23 \mathrm{~m}$ thick interval, between 75.22 and $70.99 \mathrm{~m}$ in the core (Fig. 3).

The overlying ammonite faunas with Cardioceras consist of numerous small specimens, showing the fine and dense ribbing typical of the subgenus Plasmatoceras. The 
following forms are identified: $C$. $(P$.) tenuistriatum Borissjak (Pl. 1: 5) at 70.85 and $70.37 \mathrm{~m}, C$. (P.) tenuicostatum (Nikitin) (Pl. 1: 6) at 70.80 and $70.84 \mathrm{~m}$, and C. (P.) sp. at 70.78 and $68.92 \mathrm{~m}$. These ammonites are indicative of a lower part of the Densiplicatum Zone, representing the lowermost part of the Middle Oxfordian (Sykes, Callomon, 1979). The remaining youngest Cardioceras at 68.88 and $68.56 \mathrm{~m}$ are represented by late forms of the subgenus $S u b$ vertebriceras, similar to $C$. (Subvertebriceras) zenaidae Ilovaisky ( $\mathrm{Pl} .1: 7)$. They indicate the presence of a higher part of the Densiplicatum Zone of the Middle Oxfordian (Sykes, Callomon, 1979).

All the Cardioceras faunas of the Densiplicatum Zone occur from 70.85 to $68.56 \mathrm{~m}$. The boundary between the
Lower and the Middle Oxfordian has to be place thus in a very narrow $14 \mathrm{~cm}$ thick interval between 70.99 and $70.85 \mathrm{~m}$ in the core (Fig. 3).

The deposits between 68.56 and $63.28 \mathrm{~m}$ did not yield any ammonites. Bivalves occurring in this $5.28 \mathrm{~m}$ thick interval (Entolium, Nucula) are of little stratigraphical importance. The ammonites found directly below and above indicate, however, that the stratigraphical position of the deposits devoid of ammonites may range from the upper part of the Middle Oxfordian (Tenuiserratum Zone) up to the lowermost Lower Kimmeridgian (Bauhini Zone) (see Fig. 4). It is possible that the succession is not complete. The stratigraphical gap may correspond to that which occurs between the Fuglen and the Hekkingen formations in the

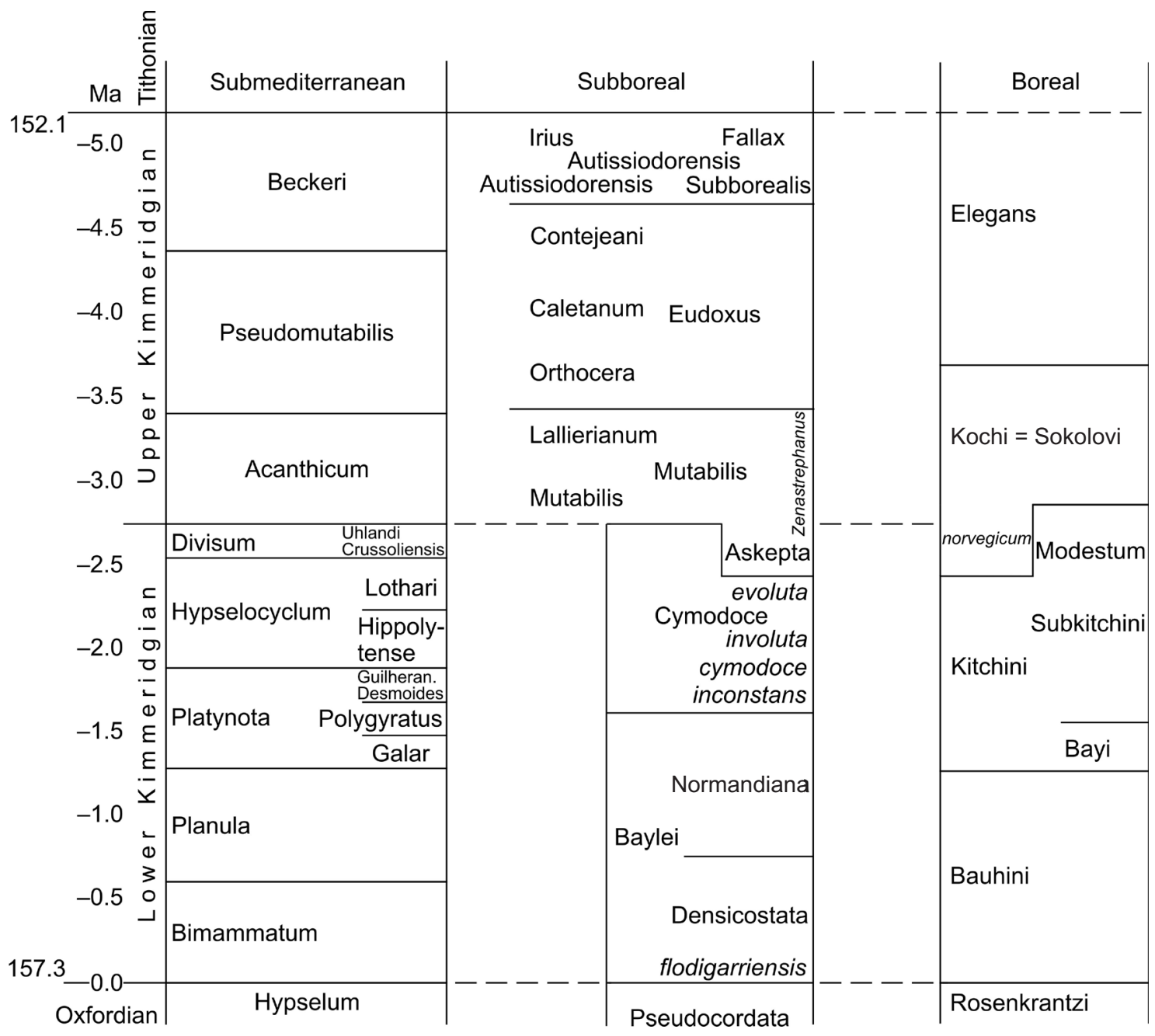

Fig. 4. Correlation of the chronobiostratigraphical ammonite zonations of the Kimmeridgian

The numerical scale of the boundaries of the stage at the left is after Ogg and Hinnov (2012), but the detailed scales are based on biostratigraphic correlations with the succession of the Early Kimmeridgian of south-eastern France where the primary sedimentary cyclicity in the term of short eccentric cycles was recognized by Boulila et al. (2010), and of the Late Kimmeridgian in the Kimmeridge Clay in England with eccentricity cycles recognized by (Huang et al., 2010). The details of the biostratigraphical correlations are according to Wierzbowski (2019, and the references given therein) 
western part of the Barents Sea, and possibly between the Oppdalen Mbr. and the Lardyfjellet Mbr of the Agardhfjellet Fm. of Svalbard, and embraces either the whole or a part of the stratigraphical interval from the upper Middle Oxfordian to the Upper Oxfordian (Smelror et al., 2001; cf. Koevoets et al., 2018, 2019).

Numerous cardioceratids of the genus Amoebites are found in the overlying deposits from 63.28 to $62.53 \mathrm{~m}$ in the core. One of these is similar to Amoebites subkitchini (Spath) at $62.66 \mathrm{~m}$, and the others to Amoebites mesezhniko$v i$ (Sykes et Surlyk) (Pl. 1: 8) at 63.28, 62.54 and $62.53 \mathrm{~m}$. The stratigraphical position of the two species is similar both occur in the Subkitchini Subzone of the middle part of the Boreal Kitchini Zone of the Lower Kimmeridgian (Wierzbowski, Rogov, 2013; Rogov, 2016).

Small aulacostephanids of the genus Rasenia (Pl. 2: 1) were encountered at 61.60 and $61.41 \mathrm{~m}$. in the core, directly above beds with $A$. mesezhnikovi. They may be compared with early species of the genus Rasenia - such as R. inconstans (Spath) and/or $R$. cymodoce (d'Orbigny). It is worth noting that the rock samples from the core which yielded Rasenia ammonites, as well as the immediately underlying sample from $61.94 \mathrm{~m}$, show the common occurrence of shells of the bivalve Buchia [identified as B. concentrica (Sowerby)] and the virtual absence of fragments of cardioceratid ammonites. The occurrence of the ammonites of the genus Rasenia indicates that the studied interval in the core, possibly from $61.94 \mathrm{~m}$, and surely between 61.60 and 61.41 $\mathrm{m}$ devoid of cardioceratids, can be correlated with some lower to middle parts of the Subboreal Cymodoce Zone of the Lower Kimmeridgian. It should be remembered that a similar replacement of the ammonite fauna with Amoebites mesezhnikovi by a new one with Rasenia cymodoce (with rare Amoebites) has been recognized in central and eastern Spitsbergen (Wierzbowski, 1989; Rogov, 2014). The interval indicates a sudden faunal turnover from cardioceratid into aulacostephanid ammonite assemblages, implying a related change in the subdivision of the Kimmeridgian from the Boreal to the Subboreal ammonite zonation (cf. Birkelund, Callomon, 1985; Wierzbowski, Smelror, 1993).

The overlying deposits further yielded a cardioceratid fauna at $60.84 \mathrm{~m}$ with numerous small ammonites referred to as Euprionoceras cf. norvegicum (Wierzbowski) (Pl. 2: 2). These occur together with bivalve Buchia cf. tenuistriata (Lahusen). This bivalve also occurs at $60.98 \mathrm{~m}$.

The ammonite Euprionoceras norvegicum (Wierzbowski) may be treated as an earliest form of the genus Euprionoceras and is indicative of the E. norvegicum horizon. The horizon has been recognized as the lowermost part of the Kochi $=$ Sokolovi Zone which was characterized by the occurrence of the ammonite Euprionoceras (Wierzbowski, Smelror, 1993). However, the E. norvegicum horizon, as de- fined by the incoming of small densely ribbed Euprionoceras ammonites, also correlates with an upper part of the Modestum Subzone, being the uppermost part of the Kitchini Zone (see Fig. 4). Such a correlation results from the cooccurrence of the first representatives of E. norvegicum with last representatives of the genus Amoebites of the A. modestum group in the cores in the southern Barents Sea ( $c f$. Wierzbowski, Smelror, 1993). Such a stratigraphical position of the E. norvegicum horizon is confirmed by new data from different areas of Europe, showing the co-occurrence or near-occurrence in the sections of the first Euprionoceras and the last Amoebites (see e.g., Wierzbowski, Rogov, 2013, fig. 4; Wierzbowski et al., 2015, fig. 2; Rogov et al., 2017). This issue is discussed below, and in the chapter on palaeobiogeography.

The succession of the two ammonite groups - the last Amoebites and the first Euprionoceras as discussed above results in the somewhat nebulous interpretation of the boundary of the two Boreal ammonite zones - the Kitchini Zone, and the Kochi $=$ Sokolovi Zone. The boundary can be placed either at the level where the last Amoebites are found, or at the level where the first Euprionoceras appear (see Fig. 4, see also Wierzbowski, Smelror, 1993). The latter interpretation is possibly better as it is more univocal and easier for recognition, although the problem needs additional studies. A very similar definition has been accepted recently for the boundary between the Oxfordian and the Kimmeridgian as defined in the Boreal cardioceratid zonation between the Rosenkrantzi Zone (uppermost Oxfordian) and the Bauhini Zone (lowermost Kimmeridgian). The base of the Bauhini Zone has been placed at the level where the first ammonites of the genus Plasmatites appear, which co-occur here with the last Amoeboceras ranging up from the underlying Rosenkrantzi Zone (Wierzbowski et al., 2018).

A younger fauna occurs from 59.98 to $58.65 \mathrm{~m}$ and is characterized by the incoming of aulacostephanid ammonites, represented by numerous specimens of Zenostephanus (formerly Xenostephanus). The specimen at $59.98 \mathrm{~m}$ (Pl. 2: 3) is very close to Zenostephanus sachsi (Mesezhnikov) (see Mesezhnikov, 1969a, p. 119-120, pl. 17: 1; pl. 19: 1; pl. 20: 1). The specimens found at 59.87, 59.40, 59.37, 58.88 and $58.71 \mathrm{~m}$ are too fragmentarily preserved to be specifically determined, although all of them belong to the genus $Z e$ nostephanus. The youngest specimen of Zenostephanus referred to as Z. scoticus (Arkell et Callomon) (Pl. 2: 4) is found at $58.65 \mathrm{~m}$ in the core.

Hence, the deposits between 59.98 to $58.65 \mathrm{~m}$ represent the Zenostephanus- rich level, which is a typical aulacostephanid horizon (Zenostephanus horizon) recognized widely in the Boreal Realm. This level may be correlated mostly with the Subboreal Mutabilis Zone (especially its part distinguished often as the Mutabilis Subzone) (see Ro- 
gov, Poulton, 2015, and references given therein; see also Fig. 4).

The youngest faunal assemblage in core $7533 / 3-\mathrm{U}-1$ occurs between $58.46 \mathrm{~m}$ (i.e. directly above the youngest recovered Zenostephanus) and it continues up to $48.47 \mathrm{~m}$. It is composed entirely of cardioceratid ammonites. The two specimens at 58.46 and $58.15 \mathrm{~m}$ are very poorly preserved and cannot be interpreted unequivocally even to the genus/ subgenus level. The rest of the very numerous (over 20) specimens from 57.66 to $48.47 \mathrm{~m}$ (in about a $9.20 \mathrm{~m}$ thick interval) belong to the genus Hoplocardioceras which is indicative of the Boreal Elegans Zone as interpreted by Wierzbowski and Smelror (1993). The genus includes two closely related species or subspecies $-H$. elegans (Spath) (Pl. 2: 5, 7, 8) and $H$. decipiens (Spath) (Pl. 2: 6), which show "at least marked overlapping if not total covering of their stratigraphic ranges which precludes the differentiation of smaller biostratigraphic units of wider importance within the Elegans Zone" (Wierzbowski, Smelror, 1993, p. 246). However, some local differences in the stratigraphical ranges of the two forms have been observed: $H$. elegans dominates in dark micaceous shales, and $H$. decipiens often occurs in the proximity of lumachelle beds ( $c f$. Wierzbowski, Smelror, 1993). In relation to the core studied $-H$. decipiens occurs together with $H$. elegans in the lowermost part of the stratigraphical range of the genus Hoplocardioceras (from 57.66 to $54.84 \mathrm{~m}$ ), whereas $H$. elegans without $H$. decipiens occurs in its middle and upper parts (from 54.72 to $48.47 \mathrm{~m}$ ).

\section{CHANGES IN AMMONITE FAUNAS AS A CLUE FOR PALAEOBIOGEOGRAPHICAL INTERPRETATION}

The stratigraphical interval from the Late Bajocian to the end of the Kimmeridgian in the studied core shows the presence of Boreal and Subboreal ammonites. All these ammonites were typical of the Boreal Realm which stretched over wide areas of high latitudes of the northern hemisphere (e.g., Cariou et al., 1985; Callomon, 2003; and earlier papers cited therein). It is commonly accepted that the Boreal ammonites, represented by the successive members of the family Cardioceratidae, developed continuously from the Late Bajocian to the end of the Kimmeridgian in parts of the Boreal Sea - a more or less enclosed circum-polar marine basin (Callomon, 1985). On the other hand, a peripheral area of the Boreal Realm was inhabited by ammonite groups of Subboreal affinities (e.g., Cariou, 1973; Matyja, Wierzbowski, 1995). These included the family Kosmoceratidae from the Middle Bathonian to the end of the Callovian, as well as the family Aulacostephanidae from the Late Oxfordian to the end of the Kimmeridgian (e.g., Birkelund et al., 1983;
Mesezhnikov, 1984; Cariou et al., 1985; Birkelund, Callomon, 1985; Matyja et al., 2006; Wright, 2010).

The distribution, and relations between the Boreal and Subboreal ammonite faunas during the Middle Jurassic is not discussed herein. This because of the poor recovery of these faunas in the present core. During the latest Callovian and Early Oxfordian to Middle Oxfordian separate Subboreal ammonite faunas as defined above did not exist due to a wide marine transgression and the opening of the Boreal Realm towards the south. Thus, the comments given below are mostly related to the palaeogeographic distribution of the ammonite faunas during the Late Oxfordian and the Kimmeridgian.

In contrast the more variegated and fluctuating environmental conditions in the Subboreal Province, the conditions of the Boreal Province were more uniform, although even here, especially during Kimmeridgian, occurred areas and levels with shales showing nothing but Buchia bivalves, and possibly deposited in an anoxic environment. In these deposits cardioceratid ammonites "occur at isolated, wellspaced but widespread horizons, suggesting infrequent and highly episodic colonization of an otherwise hostile environment" (Callomon, 1985, p. 73). The Subboreal Province was characterized by a diversified and strongly contrasted facies pattern generally related to the existence of a more shallow-water environment, compared to the deeper-water conditions in the Boreal Province (Fürsich, Sykes, 1977).

Although the Subboreal Province was originally referred to a relatively small area at the southern rim of the Boreal Realm, i.e. from North-West Europe to northern areas of the European part of Russia, west of the Ural Mountains (e.g., Sykes, Callomon, 1979), it is becoming evident that some other areas placed in more inner parts of the Boreal Realm should also be included in the Subboreal Province because of the common occurrence of the diagnostic aulacostephanids, at least in some time intervals. The intricate relations between the areas with Boreal and Subboreal ammonite faunas were first recognized in northern Central Siberia. Apparently an east-west stretching deep marine basin characterized by the occurrence of Boreal cardioceratid ammonites was developed during the Late Oxfordian to Kimmeridgian between two shallower sea areas bordering Taimyr Island to the north, and Middle Siberian Land to the south (Mesezhnikov, 1969a, b; see also Zakharov, Shurygin, 1983; Zakharov et al., 2005). This area was recognized by Mesezhnikov (1969b) as corresponding to the Taimyr-Canadian Province, coeval with the Boreal Province as interpreted herein. On the other hand, the shallower areas to north and south, bordering the land-masses mentioned were inhabited by numerous aulacostephanids typical of the Subboreal Province, and distinguished as the Greenland-Khatanga Province by Mesezhnikov (1969b). 
Another example of a specific distribution of the Boreal and Subboreal faunas is related to the existence of a deepwater marine basin of the West Siberian Sea stretching over vast areas of Western Siberia. Here the most common ammonite occurrences in the Kimmeridgian "belong to ammonite subgenus Amoeboceras (Amoebites)" (Alfirov et al., 2016) - i.e. typical faunas of the Boreal Province, although Subboreal aulacostephanids appear at some levels.

When discussing the palaeogeographic pattern of the Barents Sea area during Late Oxfordian and Kimmeridgian times, special attention should be paid to the ammonite faunas of the Nordkapp Basin (Fig. 5). During the Late Jurassic the around $300 \mathrm{~km}$ long basin in the southwestern Barents Sea represented a deep marine embayment founded on top of a Late Palaeozoic rift basin (Bugge et al., 2002). The ammonite faunas of the Late Oxfordian and Kimmeridgian studied in detail in several cores (Wierzbowski, Århus,
1990; Wierzbowski, Smelror, 1993) are here composed exclusively of different cardioceratids typical of the Boreal Province.

Core 7533/3-U-1 is from Sentralbanken High located north of the Nordkapp Basin, closer to the Svalbard Archipelago (Figs. 1, 5). The ammonite faunas consist mostly of Boreal Cardioceratidae from the Upper Bajocian up to the Middle Oxfordian and the lower part of the Lower Kimmeridgian (from 117.24 to $62.53 \mathrm{~m}$ ). In between there is an interval devoid of ammonites.

In borehole 7533/3-U-1 an abrupt appearance of the Subboreal ammonites of the genus Rasenia indicative of the lower to middle parts of the Lower Kimmeridgian Cymodoce Zone is observed at 61.60 to $61.40 \mathrm{~m}$ in the core (Figs. $3,4)$. It is evidently related to changes in environmental conditions. The same phenomenon of a sudden appearance of Rasenia ammonites, after a long time of existence of Bo-

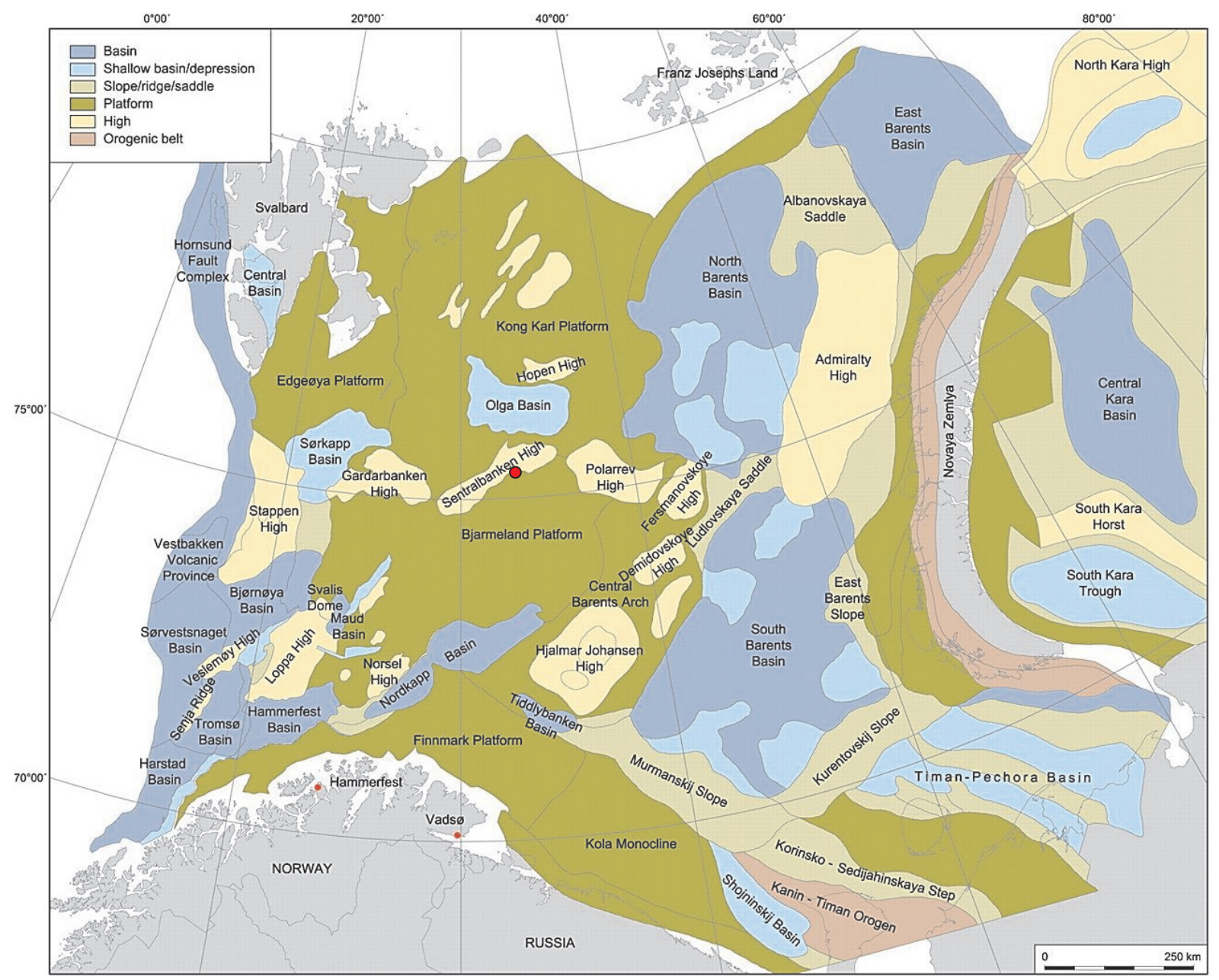

Fig. 5. Geological map showing main structural elements of the Barents Sea with location of borehole 7533/3-U-1 (in red) at the Sentralbanken High (after Henriksen et al., 2011) 
real cardioceratids, was recognized in central and eastern Spitsbergen (Wierzbowski, 1989; Rogov, 2014). It is also recognized in Andøya Island (Lofoten, northern Norway) where the Rasenia ammonites of the Cymodoce Zone appears in the Breisanden Member of the Dragneset Formation. These are the first ammonites occurring here above the disconformity between the Bajocian fluvial sediments below, and the shallow-marine deposits above (Birkelund et al., 1978; Smelror et al., 2001; with earlier references cited therein). Another common occurrence of Rasenia ammonites was initiated within the deep shelf sediments of the Alge Member of the Hekkingen Formation in the Nordland VII offshore area in the northeastern part of the Norwegian Sea (Wierzbowski et al., 2002). Much further south, outside the Boreal Realm, a sudden occurrence of the ammonite $R a$ senia cymodoce (d'Orbigny) is observed within the Submediterranean ammonite succession of Aquitaine, western France (Hantzpergue, 1989 and his earlier papers cited therein). This visit of Subboreal ammonites is approximately coeval with the Rasenia occurrences discussed above, and it indicates "the abrupt arrival which reflects an invasion from the north" (Birkelund et al., 1983, p. 305).

All these observations show that the Subboreal Rasenia ammonites appeared within a relatively short time interval in the Early Kimmeridgian, and over widespread areas. Such a migration appears to be partly tectonically induced or related to an overall transgressive phase and may correspond to rifting within the Boreal Sea, both in European and Arctic areas. The tectonic movements and relative sea-level rise resulted in flooding of previous elevated areas or shallow marine areas and deepening of shelves, such as Andøya in Northern Norway, the offshore Nordland VI and Troms III areas, and on East Greenland (Birkelund et al. 1978; Surlyk, 1978; Smelror et al., 2001; Wierzbowski et al., 2002), with possible maximum sea-level being reached in the mid Kimmeridgian (Surlyk, 1990). The overall transgression and subsidence of marine barriers would have opened new searoutes for migration and enabled the settlement and flourishing of the Subboreal ammonite faunas of Rasenia. Increased sea-water temperatures may also have played a role (e.g., Zakharov et al., 2005; Rogov, 2014), by enabling Subboreal ammonites to migrate into such a remote area of the Boreal Sea as the Svalbard and the Franz Josef Land archipelagos previously devoid of Aulacostephanidae (see e.g., Mesezhnikov, Shulgina, 1982; Mesezhnikov, 1984; Wierzbowski, 1989). This may explain the long migration route of the genus Rasenia (close to R. cymodoce) recently described from the Pacific Coast of western Canada in British Columbia (Rogov, Poulton, 2015).

The sudden appearance of the Boreal cardioceratids (Euprionoceras cf. norvegicum) at $60.84 \mathrm{~m}$ in the core has a temporarily character (Fig. 3). Immediately above, from
59.98 to $58.65 \mathrm{~m}$, once more the Subboreal aulacostephanids (Zenostephanus) occur. Nevertheless, it is important for stratigraphical and biogeographical interpretations. The occurrence of the completely new ammonite faunas composed of small-sized Euprionoceras; associated in some cores from the Barents Sea with the last Amoebites (see Wierzbowski, Smelror, 1993), as well as the appearance directly above of a new fauna of Zenostephanus, marks a major reorganization of the whole ammonite faunas of the Boreal Realm. This may be correlated with a large transgression which occurred over wide areas of the northern Tethyan Shelf near the boundary between the Early and Late Kimmeridgian, and which changed markedly the distribution and composition of the ammonite faunas in large areas of Europe (Matyja, Wierzbowski, 2000, see also Fig. 4).

The transgression is well known in the southern part of the Boreal Realm and the adjoining areas transitional to the Submediterranean Province. Here it resulted in a wide distribution of the aulacostephanid Rasenioides, gradually followed phylogenetically by Aulacostephanoides in beds distinguished as the Askepta Subzone (Birkelund et al., 1978, 1983). The Askepta Subzone is correlated with the upper part of the Cymodoce Zone in the Subboreal zonal scheme in NW Europe (i.e. the top of the Lower Kimmeridgian), or it is treated as a lower part of the Mutabilis Zone (i.e. the lowest part of the Upper Kimmeridgian) (Birkelund et al., 1978, 1983; Hantzpergue, 1989, 1995; Matyja, Wierzbowski, 2000; see also Fig. 4 herein). In this context the boundary between the Subboreal Cymodoce Zone and the Mutabilis Zone appears particularly vague as these zones are based on ammonites representing the two different aulacostephanid branches, separated not only phylogenetically, but also provincially (Birkelund et al., 1983). The Cymodoce Zone is based on the stratigraphical range of the genus Rasenia, whose natural descendent is the genus Zenostephanus. The Mutabilis Zone is based on the genus Aulacostephanoides, which natural forerunner is the genus Rasenioides (see e.g., Arkell, Callomon, 1963; Birkelund et al., 1983; Birkelund, Callomon, 1985).

Recent biostratigraphical studies in Tatarstan (central European Russia) have revealed ammonite assemblages with Rasenioides and Aulacostephanoides together with small cardioceratids of the genus Amoebites, and some forms transitional to the genus Euprionoceras. These occur along with the last raseniids (Eurasenia or Involuticeras), and directly below Zenostephanus, in the stratigraphical interval at the top of the Cymodoce Zone (Askepta Subzone), and a lower part of the Mutabilis Subzone of the Mutabilis Zone (Rogov et al., 2017, fig. 4). This, as well as observations from the cores in the Nordkapp Basin (Wierzbowski, Smelror, 1993), suggest that the older genus Amoebites was gradually replaced by the younger genus Euprionoceras at 
the transition between the Cymodoce Zone and the Mutabilis Zone sensu stricto, i.e. in the Askepta Subzone. It seems thus highly probable that the deposits at $60.84 \mathrm{~m}$ in core 7533/3-U-1, which yielded the oldest small-sized Euprionoceras referred to as E. cf. norvegicum, may correspond at least partly to the stratigraphical interval of the Askepta Subzone (Figs. 3, 4).

The ammonites of the genus Zenostephanus from 59.98 to $58.65 \mathrm{~m}$ in the core were distinguished for the first time under the name "Xenostephanus (M) - Xenostephanoides (m)" from Kimmeridgian sandy deposits of local origin in Lincolnshire, north-eastern England discovered in glacial drift (Arkell, Callomon, 1963). Two aulacostephanid assemblages were recognized therein in deposits of the same lithology, partly together in the same Quaternary locality, but partly isolated in different localities: (A) composed of Rasenia, Rasenioides and Aulacostephanoides; (B) composed of "Xenostephanus - Xenostephanoides" (i.e. of Zenostephanus as interpreted currently). Additionally, there were recognized small-sized cardioceratids of the genus Amoebites such as A. kitchini (see Arkell, Callomon, 1963, pl. 32: 26a, b) and a form described as A. cricki or cf. cricki (Arkell, Callomon, 1963, pl. 32: 25a-c) - which looks in fact very similar to early Euprionoceras. All these ammonites were treated either as of "the same age which is Mutabilis Zone sensu stricto (...)", or if not strictly coeval, "the differences of age (...) could not have been large" (Arkell, Callomon, 1963, p. 240-241).

The genus Zenostephanus is widely recognized in several Arctic areas like Franz Josef Land (Mesezhnikov, Shulgina, 1982; Repin et al., 2007), and Spitsbergen (Frebold, 1930: see Wierzbowski, 1989; Rogov, 2014; Rogov, Poulton, 2015, and earlier papers cited therein; Koevoets et al., 2018). It is also known from the Pacific Coast of western Canada (British Columbia), which occurrence possibly was a result of expansion of the Arctic areas (Rogov, Poulton, 2015). In all these areas, ammonites of the genus Rasenia were also reported, but their close phylogenetic relation was not recognized in detail. The only stratigraphical interval and area showing the continuous phylogenetical transition between the genera Rasenia-Zenostephanus through forms of Zonovia type, is the Uralensis Subzone of the Evoluta Zone in Northern Siberia at the Kheta River Basin which corresponds approximately to the Askepta Subzone (Mesezhnikov, 1969a, 1984; Saks et al., 1969a, b; see also Wierzbowski, Rogov, 2013). Here, the overlying deposits yielded also Aulacostephanoides mutabilis (Sowerby) together with Zenostephanus, corresponding to the Mutabilis Subzone. This observation strongly suggests that the occurrence of the genus Zenostephanus without Rasenia, as observed in core $7533 / 3-\mathrm{U}-1$ between 59.98 to $58.65 \mathrm{~m}$, represents the Mutabilis Subzone well above the Askepta Subzone.
The youngest deposits from 58.46 to $48.47 \mathrm{~m}$ in the studied core yielded only numerous cardioceratids. The oldest ones $(58.46$ to $58.15 \mathrm{~m})$ are poorly identifiable, but all the younger specimens belong to the genus Hoplocardioceras. This genus is indicative of the Boreal Elegans Zone of the Upper Kimmeridgian, which corresponds to the bulk of the Subboreal Eudoxus Zone, and at least a part of the Autissiodorensis Zone (Wierzbowski, Smelror, 1993; cf. Birkelund, Callomon, 1985; see also Fig. 4 herein). The wide occurrence of these cardioceratids indicates the transgression which occurred over large areas of Europe, including the Boreal Realm, during the early Eudoxus Chron (e.g., Birkelund et al., 1983; Surlyk, 1990; Hantzpergue, 1995; Gallois, 2016). This transgression flooded shallow areas in the Arctic inhabited previously by aulacostephanids, including the western Barents Sea Shelf (Smelror et al., 2001). This possibly resulted in the sudden appearance of the last members of the Aulacostephanidae lineage, such as Aulacostephanus/ Aulacostephanites, much towards the south from the circum-polar Arctic areas, and down into more southern, and shallow parts of the Boreal Realm and adjoining parts of the Submediterranean Province (see e.g., Birkelund et al., 1985).

\section{NOTES ON AMMONITE IDENTIFICATIONS AND SYSTEMATICS}

Below some notes on the identification and systematics of selected species and specimens are added. The Cranocephalites from $117.24 \mathrm{~m}$ (Pl. 1: 1a-d) comprises the phragmocone up to about $60 \mathrm{~mm}$ diameter, and the body-chamber about 0.75 of a whorl long (but without its outer part - cut off during drilling). However, the whole specimen reached about $70 \mathrm{~mm}$ in diameter. The ribbing is uniformly fairly dense in the phragmocone (about 20 primary ribs per whorl), consisting of similarly developed primary and secondary ribs, but the ribs become more widely spaced and coarser at the end of phragmocone - beginning of the body-chamber, and the ribbing finally disappears at the end of body-chamber. These features show that the specimen may be referred to Cranocephalites indistinctus Callomon, showing especially large similarity to the form recognized as Cranocephalites indistinctus trans $\alpha$ ' of Callomon et al. (2015, pl. 5: 1-3). Another ammonite from $115.67 \mathrm{~m}$ is a fragment of the inner whorls of a young specimen possibly about $25 \mathrm{~mm}$ in diameter (Pl. 1: 2). The ribbing consists of biplicate ribs with some intercalatory ribs in the outer part of whorl (the secondary/primary ribs ratio equals about 2.5; the primary ribs are strongly prorisiradiate, and the secondaries show a rectiradiate course). This character of ribbing is typical of the inner whorls of several species of Cranocephalites 
- except the oldest one $-C$. borealis (Spath), all of them showing similarly developed primary and secondary ribs (see Callomon, 1993; Callomon et al., 2015).

The specimen found at $99.42 \mathrm{~m}$ is assigned to Kepplerites. This is about $25 \mathrm{~mm}$ in diameter, shows evolute coiling, and has short primary ribs which become more distant on the outer whorl preserved. The specimen resembles very much the inner whorls of Kepplerites, and it can be safely referred that genus. However, a more detailed determination is difficult. The specimen from $94.60 \mathrm{~m}$ is also small, about $25 \mathrm{~mm}$ in diameter, shows involute coiling, markedly prorsiradiate strong ribs, and very deep umbilicus. The specimen is undoubtedly a cadoceratid, and may be attributed to Pseudocadoceras as it shows the microconch morphology of the cadoceratoid type.

The ammonite from $75.22 \mathrm{~m}$ may be referred to the genus Longaeviceras. It is large and heavily flattened specimen, showing a narrow umbilicus, and moderately dense ribbing with a fairly low and irregular point of ribs' division (Pl. 1: 3). It is close to late representatives of the genus such as L. placenta (Leckenby) and L. longaevum (Leckenby), which show a similar morphology, and rather minor differences, doubtfully "more than varietal" in character (Callomon, Wright, 1989).

The ammonites of the genus Cardioceras include the type species $-C$. $(C$.) cordatum (Sowerby) at $70.99 \mathrm{~m}$ (Pl. 1: 4) with the primaries well differentiated and looselyplaced, and the numerous, well separated and strongly accentuated secondaries. The finely ribbed subgenus Plasmatoceras is represented by specimens belonging to two species: (1) a more distinctly ribbed $C$. $(P$.) tenuicostatum (Nikitin), and (2) the weakly ribbed $C$. $(P$.) tenuistriatum Borissiak, the latter includes also a very densely ribbed specimen at $70.37 \mathrm{~m}$ (Pl. 1: 5), somewhat resembling in its very delicate ribbing a younger Miticardioceras. The youngest specimen of the genus Cardioceras at $68.56 \mathrm{~m}$ (Pl. 1: 7) shows strongly developed ribbing consisting of looselyspaced primaries, and short secondaries, as well as a coarsely serrated keel. These are typical features of the subgenus Subvertebriceras and the specimen can be attributed to Cardioceras (Subvertebriceras) zenaidae Ilovaisky. The discontinuity between the primary and secondary ribs along with the presence of strongly developed mid-lateral and ventrolateral tubercles observed at the end of the last whorl preserved, representing already the beginning of the bodychamber, approaches somewhat Maltoniceras as well as Cawtoniceras.

Numerous cardioceratids of the genus Amoebites are found in the overlying deposits from 63.28 to $62.53 \mathrm{~m}$ in the core. Two forms may be distinguished based mostly on fragmentarily preserved specimens (some of a larger size with whorl-height attaining even $30 \mathrm{~mm}$ ): one similar to Amoe- bites subkitchini (Spath) at $62.66 \mathrm{~m}$, and another to Amoebites mesezhnikovi (Sykes et Surlyk) (Pl. 1: 8) at 63.28, 62.54 , and $62.53 \mathrm{~m}$. These two species are closely related, and differ mostly in the number of secondary ribs (or corresponding ventrolateral tubercles at growing diameters), which is larger in A. mesezhnikovi (see Wierzbowski, 1989; see also Sykes, Surlyk, 1976).

The small aulacostephanids of the genus Rasenia (Pl. 2: 1) encountered at 61.60 and $61.41 \mathrm{~m}$. show weakly evolute coiling, short primary ribs (26 primary ribs per whorl), and about 2-3 secondaries per each primary rib at about $35 \mathrm{~mm}$ diameter. The constrictions are fairly prominent, bordered by stronger ribs. The specimens are too small for unequivocal specific determination. However, the character of ornamentation suggests that they may be compared with early species of the genus Rasenia - such as R. inconstans (Spath) and/or $R$. cymodoce (d'Orbigny).

The cardioceratid fauna found at $60.84 \mathrm{~m}$ is composed of numerous small specimens referred to as Euprionoceras cf. norvegicum (Wierzbowski). They are about $12-15 \mathrm{~mm}$ in diameter. All of them show the inner whorls up to about $10 \mathrm{~mm}$ in diameter, almost smooth or covered by thin striae, followed by biplicate ribs splitting high on the whorl side, and additionally some intercalatory ribs. All these specimens, although poorly preserved, may be referred to as $\mathrm{Eu}$ prionoceras cf. norvegicum (Wierzbowski) (Pl. 2: 2). Such small-sized forms showing dense and rather weak ribbing without markedly developed tubercles represent a fragment of the cardioceratid lineage preceding the appearance of large forms of the genus Euprionoceras (see Wierzbowski, Rogov, 2013, fig. 4; Wierzbowski, Smelror, 1993).

The ammonite fauna from 59.98 to $58.65 \mathrm{~m}$ is represented by numerous specimens of Zenostephanus (formerly Xenostephanus) which show characteristic ornamentation and coiling typical of the genus, but as the specimens are strongly flattened they do not reveal the ventral side of the whorl with the characteristic smooth band. The oldest specimen at $59.98 \mathrm{~m}$ (Pl. 2: 3) is very close to Zenostephanus sachsi (Mesezhnikov) (see Mesezhnikov, 1969a, p. 119-120, pl. 17: 1; pl. 19: 1; pl. 20: 1). It is about $70-80 \mathrm{~mm}$ in diameter (not complete), shows about $12-13$ primary ribs per half a whorl at $30-70 \mathrm{~mm}$ diameter, bi- and triplicate ribs on the last whorl, and a constriction bordered in its front by a single rib. Several younger specimens found at 59.87, 59.40, $59.37,58.88$ and $58.71 \mathrm{~m}$ are too fragmentarily preserved to be specifically determined, although all of them belong to the genus Zenostephanus.

The youngest specimen of Zenostephanus found at $58.65 \mathrm{~m}$ in the core is well preserved (Pl. 2: 4). The specimen attains about $70 \mathrm{~mm}$ in diameter as calculated from the preserved fragment in the core. It consists of a phragmocone up to about $65 \mathrm{~mm}$ diameter, and a fragment of the body- 
chamber. Its inner whorls up to $15 \mathrm{~mm}$ diameter show triplicate ribs of the Rasenia type, but soon thereafter biplicate ribs occur commonly, covering the next three whorls; the ribbing consists of strong short primaries separated from secondaries by a smooth band - which is typical feature of Zenostephanus. The ribbing is dense (from about 24 primary ribs per whorl at $20 \mathrm{~mm}$ diameter up to 33 at $50 \mathrm{~mm}$ diameter). More loosely spaced triplicate ribs appear on the part of the outer whorl preserved. The coiling is very evolute (at 52 $\mathrm{mm}$ diameter, the whorl height and the umbilical width represent $28 \%$, and $47.1 \%$ of the diameter, respectively). The specimen compares well with several macroconchs of $\mathrm{Ze}$ nostephanus from Franz Josef Land described under the name Zonovia aff. sachsi Mesezhnikov by Mesezhnikov, Shulgina (1982, p. 28, fig. 3a, b) and Zonovia (Xenostephanus) sachsi Mesezhnikov by Repin et al. (2007, pl. 12: 2a, b; pl. 14: 1, 2a, b, 4). However, all these specimens differ from typical specimens of $Z$. sachsi in several features, such as a markedly denser ribbing and the dominant biplicate ribs in the middle whorls ( $c f$. Mesezhnikov, Shulgina, 1982; see also Mesezhnikov, 1984). Very similar specimens referred to as "Rasenia sp. indet. cf. groenlandicus Ravn" have been described by Frebold (1930, p. 62, pl. 22: 2) from Spitsbergen and these "may well be more closely related to Xenostephanus" (i.e. Zenostephanus as currently interpreted) (Birkelund, Callomon, 1985, p. 39-40). The form represented by the discussed specimens thus deserves to be distinguished as a separate species.

There is no doubt that the discussed specimens, showing the common occurrence of biplicate ribs in the middle whorls which are rather densely-placed, represent another species of the genus Zenostephanus than the more heavily ornamented species like Z. ranbyensis (Arkell et Callomon) or Z. sachsi (Mesezhnikov). It should be also remembered that the discussed specimens show marked similarity to such forms as "Rasenia" borealis Spath (see Spath, 1935, pl. 6: 1; pl. 7; and Birkelund and Callomon, 1985, pl. 15: 2; pl. 21: 2, 3) but also "Aulacostephanus" groenlandicus Ravn (see Birkelund, Callomon, pl. 21:1a, b; see also Sykes and Surlyk, 1976, fig. 7A) which are, however, less evolute and show less swollen primary ribs. The only species which is close to the discussed specimens of Zenostephanus is Zenostephanus scoticus (Arkell et Callomon), as based on a fragmentarily preserved aulacostephanid ammonite from Scotland, illustrated by Spath $(1935$, p. 49, pl. 13: 8a, b). It was originally recognized as a microconch of Xenostephanus $=$ Zenostephanus, and thus placed in the subgenus Xenostephanoides by Arkell and Callomon (1963), but such a dimorphic interpretation is not well settled. The name Zenostephanus scoticus (Arkell et Callomon) when used both for macro- and microconchs may be thus introduced for the discussed specimen from the present core (Pl. 2: 4).
The moderately to heavily ornamented ammonites recognized at the top of the succession of the core from 57.66 to $48.47 \mathrm{~m}$ show commonly the presence of the ventrolateral nodes and clavi typical of Hoplocardioceras elegans (Spath) (Pl. 2: 5, 8). The largest of them are represented as a part of the final whorl with ventral rostrum, attaining even about 40-45 mm in whorl height (specimens from 54.22 and $49.49 \mathrm{~m})$, which indicates that the whole specimen may have reached even about $140 \mathrm{~mm}$ in diameter (cf. Wierzbowski, 1989, pl. 21: 3). Some of the specimens like that from $54.84 \mathrm{~m}$ (Pl. 2: 7) show more sparsely-placed ribbing at a diameter about $25 \mathrm{~mm}$ and strongly accentuated nodes in the ventrolateral and middle part of the whorl, resembling somewhat the three-tuberculate $H$. decipiens (Spath). The small specimen from $56.83 \mathrm{~m}(\mathrm{Pl} .2:$ 6) showing three well developed rows of tubercles, already at about $20 \mathrm{~mm}$ diameter and sparse ribbing (about 25 ribs per whorl), is attributed to Hoplocardioceras decipiens (Spath).

\section{CONCLUSIONS}

The Jurassic succession in core 7533/3-U-1 from the Sentralbanken High of the Barents Sea can lithostratigraphically be subdivided into the Fuglen and Hekkingen Formations with their boundary at $71.52 \mathrm{~m}$, and biostratigraphically into three parts showing different ammonite assemblages and sedimentary patterns: the lowest corresponding to the Middle Jurassic (117.24 to $75.22 \mathrm{~m}$ ), the middle corresponding to the Oxfordian and Lower to lowermost part of the Upper Kimmeridgian (70.99-58.65 m), and the upper corresponding mostly to the Upper Kimmeridgian Elegans Zone (and the Subboreal Eudoxus Zone) from 58.46 to 48.47 m (Figs. 2, 3). These can be compared with coeval, stratigraphically well described deposits of Spitsbergen and elsewhere in the Arctic.

The oldest part includes nearly the whole Middle Boreal Jurassic from the Upper Bajocian to the Upper Callovian and is fairly complete (i.e. defined from the base, middle and top by ammonites and not showing any sedimentological features of discontinuities), attaining about 43 metres in thickness. It is stratigraphically more complete than the corresponding Middle Jurassic deposits of the Svalbard Archipelago. The latter as known from Spitsbergen are generally thinner, although showing some local differences in thicknesses and possibly in stratigraphical range of the deposits. The deposits are possibly not older than the Middle Boreal Bathonian (Cranocephaloide Zone), as shown by the presence of ammonites of the genus Kepplerites in the central part of Spitsbergen - in the Sassenfjorden area (Kopik, Wierzbowski, 1988, and earlier papers cited therein), but locally also older - of the Early Bathonian age (Ishmae Zone), 
as proved by occurrence of Arcticoceras, in eastern and southern Spitsbergen ( $c f$. Ershova, 1983). A similar assemblage of ammonites of Early Bathonian age composed mostly of Arcticoceras from the Oppdalen Member, in the lowermost part of the transgressive deposits of the Agardhfjellet Formation (cf. Smelror et al., 2019) was described by Rawson (1982) from Kong Karls Land in the southern part of the Svalbard Archipelago. Such a stratigraphical interpretation of the Boreal ammonite faunas of Arcticoceras as corresponding to the Lower Bathonian (originally interpreted as indicative of the Boreal Middle Bathonian, e.g., Callomon, 2003), results from recent studies of the ammonite succession in the Saratov area, central part of the Russian Platform (Mitta et al., 2014, and earlier papers of the authors cited therein).

The stratigraphical interpretation of the middle part of the succession in the studied core shows that sedimentation has been very slow and condensed at least from the uppermost Callovian, through the whole Oxfordian, and a large part of the Kimmeridgian (possibly up to the lower part of the Elegans Zone). The total thickness of these deposits cannot be accurately determined, but it is between 12.65 and $16.57 \mathrm{~m}$. The succession is possibly incomplete, with a probable stratigraphical gap including the upper part of the Middle Oxfordian, as well as a part of the Upper Oxfordian (see chapter on ammonite stratigraphy). It is also worth noting the occurrence of the stratigraphical interval between 68.56 and $63.28 \mathrm{~m}$ devoid of ammonites and with a poor bivalve fauna. This suggests the temporary existence of unfavorable environmental conditions for the development of the ammonite fauna. The total thickness of the deposits is markedly smaller than in Spitsbergen where coeval deposits may attain even about 70 metres in thickness (Koevoets et al., 2018).

The upper part of the succession corresponding mostly to the Elegans Zone is more uniform and relatively thick. The deposits of the Elegans Zone (at least partly the equivalent of the Eudoxus Zone) correspond to the transgressive deposits of the younger part of the Hekkingen Formation formed on the western Barents Sea shelf during times of maximum flooding (see e.g., Smelror et al., 2001).

The described succession from core 7533/3-U-1 shows marked similarities in the general development of facies and the ammonite successions to those known from East Greenland and the shelf off western and mid Norway, as well as the North Sea area. The formation of the successions was governed by the rifting which appeared in Late Bajocian to Middle Bathonian and intensified in the Late Oxfordian and Kimmeridgian (Surlyk, 2003, and earlier papers cited therein). The rifting produced elevated fault-blocks, such as the one corresponding to the middle part of the succession studied in the core. The tectonic processes and the climatically- controlled sedimentary cycles resulted also in the marine transgressions, peaking in the Late Kimmeridgian Eudoxus Chron (Elegans Chron). The recovered ammonites from the Upper Bajocian to the Upper Kimmeridgian comprise mostly Boreal Cardioceratidae, but the incoming of Subboreal Aulacostephanidae at two Kimmeridgian intervals offers possibilities to gain insight into fluctuations between the Boreal and Subboreal provinces during the tectonicly active Late Jurassic time.

Acknowledgements. Thanks are due to the Norwegian Petroleum Directorate for permission to publish the present study from borehole 7533/3-U-1 on the Sentralbanken High drilled in 1990 by SINTEF Petroleum Research. The core$\log$ presented in Fig. 2 was produced by Vidar Fjerdingstad, Geir Birger Larssen and Atle Mørk, but it has been modified according to the stratigraphical interpretation of the succession as given herein. We are grateful to the editorial referees: Peter Alsen and Mikhail A. Rogov - for their critical reviews of the manuscript; even if the authors did not follow all of the suggestions of the referees - the critical analysis of all the aspects of the reviews helped in improving the present study. We are also grateful to Bronisław A. Matyja for kind help in determination of ammonites of the genus Cardioceras. Special thanks are to Błażej Błażejowski and Marian Dziewiński for kind preparation of the photos of ammonites.

The part of the study dealing with ammonite faunas, the chronostratigraphical interpretation of the deposits and palaeobiogeography was prepared by one of the authors (AW), whereas the second author (MS) was responsible for lithological description of the deposits and the geological setting of the area of study.

\section{REFERENCES}

ALFIROV A.S., BEISEL A.L., MELEDINA S.V., 2016 - The Callovian and Late Jurassic ammonite-based chronostratigraphy of West Siberia: important findings, biostratigraphic review, and basin correlation West Siberia-South England. Swiss Journal of Palaeontology, 135, 1: 11-21.

ARKELL W.J., 1941 - The Upper Oxford Clay at Purton, Wilts and the zones of the Lower Oxfordian. Geological Magazine, 78: $161-172$.

ARKELL W.J., CALLOMON J.H., 1963 - Lower Kimmeridgian ammonites from the drift of Lincolnshire. Palaeontology, 6, 2: 219-245.

BIRKELUND T., CALLOMON J.H., 1985 - The Kimmeridgian ammonite faunas of Milne Land, central East Greenland. Grønlands Geologiske Undersøgelse, 153: 1-56.

BIRKELUND T., THUSU B., VIGRAN J., 1978 - Jurassic-Cretaceous biostratigraphy of Norway, with comments on the British Rasenia cymodoce Zone. Palaeontology, 21, 1: 31-63. 
BIRKELUND T., CALLOMON J.H., CLAUSEN C.K., NØHR HANSEN H., SALINAS I., 1983 - The Lower Kimmeridge Clay at Westbury, Wiltshire, England. Proceedings of the Geologists' Association, 94, 4: 289-309.

BOULILA S., de RAFELIS M., HINNOV L.A., GARDIN S., GALBRUN B., COLLIN P.Y., 2010 - Orbitally forced climate and sea-level changes in the Palaeoceanic Tethyan domain (marl-limestone alternations, Lower Kimmeridgian, SE France). Palaeogeography, Palaeoclimatology, Palaeoecology, 292: 57-70.

BUGGE T., MANGERUD G., ELVEBAKK G., MØRK A., NILSSON I., FANAVOLL S., VIGRAN J.O., 1995 - The Upper Palaeozoic succession on the Finnmark Platform, Barents Sea. Norsk Geologisk Tidsskrift, 75: 3-30.

BUGGE T., ELVEBAKK G., FANAVOLL S., MANGERUD G., SMELROR M., WEISS H.M., GJELBERG J., KRISTENSEN S.E., NILSEN K., 2002 - Shallow stratigraphic drilling applied in hydrocarbon exploration of the Nordkapp Basin, Barents Sea. Marine and Petroleum Geology, 19: 13-37.

CALLOMON J.H., 1975 - Jurassic ammonites from the northern North Sea. Norsk Geologisk Tidsskrift, 55: 373-386.

CALLOMON J.H., 1985 - The evolution of the Jurassic ammonite family Cardioceratidae. Special Papers in Palaeontology, 33 : 49-90.

CALLOMON J.H., 1993 - The ammonite succession in the Middle Jurassic of East Greenland. Bulletin of the Geological Society of Denmark, 40: 83-113.

CALLOMON J.H., 2003 - The Middle Jurassic of western and northern Europe: its subdivisions, geochronology and correlations. Geological Survey of Denmark and Greenland Bulletin, 1: $67-73$.

CALLOMON J.H., WRIGHT J.K., 1989 - Cardioceratid and kosmoceratid ammonites from the Callovian of Yorkshire. $\mathrm{Pa}$ laeontology, 32, 4: 799-836.

CALLOMON J.H., ALSEN P., SURLYK F., 2015 - The ammonites of the Middle Jurassic Cranocephalites beds of East Greenland. Geological Survey of Denmark and Greenland Bulletin, 34: 1-148.

CARIOU E., 1973 - Ammonites of the Callovian and Oxfordian, 287-295. In: Atlas of Palaeobiogeography (Ed. A. Hallam). Elsevier Scientific Publishing Company. Amsterdam-LondonNew York.

CARIOU E., CONTINI D., DOMMERGUES J.L., ENAY R., GEYSSANT J.R., MANGOLD C., THIERRY J., 1985 - Biogéographie des ammonites et evolution structural de la Téthys au cours du Jurassique. Bulletin de la Societé Géologique de France, sér. 8, 1, 5: 679-697.

ERSHOVA E.S., 1983 - Obyasnitelnaya zapiska k biostratigraphicheskoy scheme yurskikh i nizhniemelovikh otlozhenyi arkhipelaga Spitsbergen. Ministerstvo Geologoyi SSSR, PGO "Sevmorgeogeologiya", Leningrad.

FREBOLD H., 1930 - Verbreitung und Ausbildung des Mesozoikums in Spitsbergen. Skrifter om Svalbard og Ishavet, 31: $1-127$.

FÜRSICH F.T., SYKES R.M., 1977 - Palaeobiogeography of the European Boreal Realm during Oxfordian (Upper Jurassic) times: a quantitative approach. Neues Jahrbuch für Geologie und Paläontologie, Abhandlungen, 155, 2: 137-161.
GALLOIS R., 2016 - The stratigraphy of the Kimmeridge Clay Formation (Jurassic) at Westbury, Wiltshire U.K. Proceedings of the Geologists' Association, 127: 280-287.

HANTZPERGUE P., 1989 - Les ammonites kimméridgiennes du haut-fond d'Europe occidentale: biochronologie, systématique, evolution, paléobiogéographie. Cahiers de Paléontologie. Édition du Centre de la Recherche Scientifique, Paris.

HANTZPERGUE P., 1995 - Faunal trends and sea-level changes: biostratigraphic patterns of Kimmeridgian ammonites on the Western European Shelf. Geologische Rundschau, 84: 245-254.

HENRIKSEN E., RYSETH A.E., LARSSEN G.B., HEIDE T., RONNING K., SOLLID K., STOUPAKOVA A.V., 2011 - Tectonostratigraphy of the greater Barents Sea: implications for petroleum systems. Geological Society of London, Memoirs, 35: $1-63$.

HUANG C., HESSELBO S.P., HINNOV L., 2010 - Astrochronology of the late Jurassic Kimmeridge Clay (Dorset, England) and implications for Earth system processes. Earth and Planetary Science Letters, 289: 242-255.

KISELEV D.N., ROGOV M.A., 2018 - Detailed biostratigraphy of the Middle Callovian - lowest Oxfordian in the Mikhaylov reference section (Ryazan region, European part of Russia) by ammonites. Volumina Jurassica, 16: 73-186.

KOEVOETS M.J., HAMMER Ø., OLAUSSEN S., SENGER K., SMELROR M., 2018 - Integrating subsurface and outcrop data of the Middle Jurassic to Lower Cretaceous Agardhfjellet Formation in central Spitsbergen. Norwegian Journal of Geology, 98, 4: 1-34.

KOEVOETS M.J., HAMMER Ø., LITTLE C.T., 2019 - Palaeoecology and palaeoenvironments of the Middle Jurassic to lowermost Cretaceous Agardhfjellet Formation (Bathonian-Ryazanian), Spitsbergen, Svalbard. Norwegian Journal of Geology, 99, 1: 1-24.

KOPIK J., WIERZBOWSKI A., 1988 - Ammonites and stratigraphy of the Bathonian and Callovian at Janusfjellet and Wimanfjellet, Sassenfjorden, Spitsbergen. Acta Palaeontologica Polonica, 33, 2: 145-168.

MATYJA B.A., WIERZBOWSKI A., 1995 - Biogeographic differentiation of the Oxfordian and Early Kimmeridgian ammonite faunas of Europe, and its stratigraphic consequences. Acta Geologica Polonica, 45, 1/2: 1-8.

MATYJA B.A., WIERZBOWSKI A., 2000 - Biostratigraphical correlations between the Subboreal Mutabilis Zone and the Submediterranean upper Hypselocyclum - Divisum zones of the Kimmeridgian: new data from northern Poland. GeoResearch Forum, 6: 129-136.

MATYJA B.A., WIERZBOWSKI A., WRIGHT J.K., 2006 - The Sub-Boreal/Boreal ammonite succession at the Oxfordian/Kimmeridgian boundary at Flodigarry, Staffin Bay (Isle of Skye), Scotland. Transactions of the Royal Society of Edinburgh, Earth Sciences, 96: 387-405.

MELEDINA S.W., 1973 - Ammonites and zonal stratigraphy of the Bajocian-Bathonian of Siberia. Trudy Instituta Geologii i Geofizyki Akademii Nauk SSSR, 153: 1-152 (in Russian).

MELEDINA S.W., 1977 - Ammonites and zonal stratigraphy of the Callovian of Siberia. Transactions of Academy of Sciences of the USSR, Siberian Branch, Institute of Geology and Geophysics, 356: 1-290 (in Russian). 
MESEZHNIKOV M.S., 1969a - Kimmeridgian ammonites, 99124. In: Fundamental section of the Upper Jurassic of Kheta River Basin (Ed. V.N. Saks). Nauka, Leningrad (in Russian).

MESEZHNIKOV M.S., 1969b - Zonal stratigraphy and zoogeographical subdivision of the marine basins. Geologiya $i$ Geofizika, 10, 7: 45-53 (in Russian).

MESEZHNIKOV M.S., 1984 - Kimmeridgian and Volgian of the North of the USSR. Nauka, Leningrad (in Russian).

MESEZHNIKOV M.S., SHULGINA N.I., 1982 - Kimmeridgian ammonites and new data on stratigraphy of the northern part of USSR. Geologiya i Geofizika, 10: 19-30 (in Russian).

MITTA V., KOSTYLEVA V., DZYUBA O., GLINSKIKH L., SHURYGIN B., SELTZER V., IVANOV A., URMAN O., 2014 - Biostratigraphy and sedimentary settings of the Upper Bajocian - Lower Bathonian in the vicinity of Saratov (Central Russia). Neues Jahrbuch für Geologie und Paläontologie, Abhandlungen, 271, 1: 95-121.

OGG J.G., HINNOV L.A., 2012 - Jurassic: 732-791. In: The Geologic Time Scale (Eds F.M. Gradstein et al.). Elsevier B.V.

RAWSON P.F., 1982 - New Arctocephalitinae (Ammonoidea) from the Middle Jurassic of Kong Karls Land, Svalbard. Geological Magazine, 119, 1: 95-100.

REPIN Y.S., FEDOROVA A.A., BISTROVA V.V., KULIKOVA N.K., POLUBOTKO I.V., 2007 - Mesozoic of the Barents Sea sedimentological basin, 112-161. In: Stratigraphy and its role in develop of oil and gas complexes of Russia (Eds A.V. Kirichkova, T.V. Dmitrieva). VNIGRI, Saint-Petersburg (in Russian).

ROGOV M.A., 2014 - An infrazonal ammonite biostratigraphy for the Kimmeridgian of Spitsbergen. Norwegian Petroleum Directoriate Bulletin, 11: 153-165.

ROGOV M.A., 2016 - New zonal and infrazonal scales for the Kimmeridgian in Western Siberia based on cardioceratid ammonites. Stratigraphy and Geological Correlation, 24, 5: 6790.

ROGOV M.A., POULTON T.P., 2015 - Aulacostephanid ammonites from the Kimmeridgian (Upper Jurassic) of British Columbia (western Canada) and their significance for correlation and palaeobiogeography. Bulletin of Geosciences, 90, 1: 7-20.

ROGOV M.A., WIERZBOWSKI A., SHCHEPETOVA E., 2017 Ammonite assemblages in the Lower to Upper Kimmeridgian boundary interval (Cymodoce to Mutabilis zones) of Tatarstan (central European Russia) and their correlation importance. Neues Jahrbuch für Geologie und Paläontologie, Abhandlungen, 285, 2: 161-185.

SAKS V.N., BASOV V.A., MESEZHNIKOV M.S., RONKINA Z.Z., SHULGINA N.I., 1969a - Stratigraphical conclusions and correlations, 64-92. In: Fundamental section of the Upper Jurassic of Kheta River Basin (Ed. V.N. Saks). Nauka, Lenin$\operatorname{grad}$ (in Russian).

SAKS V.N., RONKINA Z.Z., BASOV V.A., ZAKHAROV V.A., MESEZHNIKOV M.S., SHULGINA N.I., YUDOVNY E.G., $1969 b$ - Description of strata of reference section, 14-62. In: Fundamental section of the Upper Jurassic of Kheta River Basin (Ed. V.N. Saks). Nauka, Leningrad (in Russian).

SMELROR M., MØRK A., MØRK M.B.E., WEISS H.M., LØSETH H., 2001 - Middle Jurassic-Lower Cretaceous trans- gressive-regressive sequences and facies distribution off Nordland and Troms, Norway, 211-232. In: Sedimentary Environments Offshore Norway - Palaeozoic to Recent (Eds O.J. Martinsen, T. Dreyer). NPF Special Publication 10, Elsevier Science B.V., Amsterdam.

SMELROR M., LARSSEN G.B., OLAUSSEN S., RØMULD A., WILLIAMS R., 2019 - Late Triassic to early Cretaceous palynostratigraphy of Kong Karls Land, Svalbard, Arctic Norway with correlations to Franz Josef Land, Arctic Russia. Norwegian Journal of Geology, 98, 4: 1-31.

SPATH L.F., 1935 - The Upper Jurassic invertebrate faunas of Cape Leslie, Milne Land. I. Oxfordian and Lower Kimmeridgian. Meddelelser om Grønland, 99, 2: 1-78.

SURLYK F., 1978 - Mesozoic geology and palaeogeography of Hochstetter Forland, East Greenland. Bulletin of Geological Society of Denmark, 27: 73-87.

SURLYK F., 1990 - A Jurassic sea-level curve for East Greenland. Palaeogeography, Palaeoclimatology, Palaeoecology, 78: 71-85.

SURLYK F., 2003 - The Jurassic of East Greenland: a sedimentary record of thermal subsidence, onset and culmination of rifting. Geological Survey of Denmark and Greenland Bulletin, 1: 659-722.

SYKES R.M., CALLOMON J.H., 1979 - The Amoeboceras zonation of the Boreal Upper Oxfordian. Palaeontology, 22, 4: 839-903.

SYKES R.M., SURLYK F., 1976 - A revised ammonite zonation of the Boreal Oxfordian and its application in northeast Greenland. Lethaia, 9: 421-436.

VIGRAN J.O., MANGERUD G., MØRK A., WORSLEY D., HOCHULI P.A., 2014 - Palynology and geology of the Triassic succession of the Svalbard and Barents Sea. Geological Survey of Norway Special Publication, 14: 1-270.

WIERZBOWSKI A., 1989 - Ammonites and stratigraphy of the Kimmeridgian at Wimanfjellet, Sassenfjorden, Spitsbergen. Acta Palaeontologica Polonica, 34, 4: 355-378.

WIERZBOWSKI A., 2019 - Kimmeridgian Stage: its boundaries, subdivision, palaeobiogeography, and stratigraphical correlations in Europe: 180-183. In: XIVth Jurassica Conference, Bratislava, Slovakia, June 10-14, 2019 (Eds K. Fekete et al.). Field trip and Abstracts Book. Bratislava, 2019.

WIERZBOWSKI A., ÅRHUS N., 1990 - Ammonite and dinoflagellate cyst succession of an Upper Oxfordian - Kimmeridgian black shale core from the Nordkapp Basin, southern Barents Sea. Newsletter on Stratigraphy, 22, 1: 7-19.

WIERZBOWSKI A., ROGOV M.A., 2013 - Biostratigraphy and ammonites of the Middle Oxfordian to lowermost Kimmeridgian in northern Central Siberia. Russian Geology and Geophysics, 54: 1083-1102.

WIERZBOWSKI A., SMELROR M., 1993 - Ammonite succession in the Kimmeridgian of southwestern Barents Sea, and the Amoeboceras zonation of the Boreal Kimmeridgian. Acta Geologica Polonica, 43, 3/4: 229-249.

WIERZBOWSKI A., SMELROR M., MØRK A., 2002 - Ammonites and dinoflagellate cysts in the Upper Oxfordian and Kimmeridgian of the northeastern Norwegian Sea (Nordland VII area): Biostratigraphical and biogeographical significance. Neues Jahrbuch für Geologie und Paläontologie, Abhandlungen, 226, 2: 145-164. 
WIERZBOWSKI A., SMOLEŃ J., IWAŃCZUK J., 2015 - The Oxfordian and Lower Kimmeridgian of the Peri-Baltic Syneclise (north-eastern Poland): stratigraphy, ammonites, microfossils (foraminifers, radiolarians), facies and palaeogeographical implications. Neues Jahrbuch für Geologie und Paläontologie, Abhandlungen, 277, 1: 63-104.

WIERZBOWSKI A., MATYJA B.A., WRIGHT J.K., 2018 - Notes on evolution of the ammonite families Aulacostephanidae and Cardioceratidae of the uppermost Oxfordian and lowermost Kimmeridgian in the Staffin Bay (Isle of Skye, Northern Scotland). Volumina Jurassica, 16: 27-50.

WORSLEY D., JOHANSEN R., KRISTENSEN S.E., 1988 - The Mesozoic and Cenozoic succession of Tromsøflaket. In: A lithostratigraphic scheme for the Mesozoic and Cenozoic succes- sion offshore mid- and northern Norway (Eds A. Dalland et al.). Norwegian Petroleum Directorate Bulletin, 4: 42-65.

WRIGHT J.K., 2010 - The Aulacostephanidae (Ammonoidea) of the Oxfordian/Kimmeridgian boundary beds (Upper Jurassic) of southern England. Palaeontology, 53, 1: 11-52.

ZAKHAROV V.A., SHURYGIN B.N., 1983 - Geographical differentiation of the marine bivalves of the Jurassic and Early Cretaceous Arctic Zoogeographical Realm. Transactions of Institute of Geology and Geophysics, Siberian Branch of Academy of Sciences of USSR, 555: 72-88 (in Russian).

ZAKHAROV V.A., BAUDIN F., DZYUBA O.S., DAUX V., ZVEREV K.V., RENARD M., 2005 - Isotopic and faunal record of high palaeotemperatures in the Kimmeridgian of the Subpolar Urals. Geologiya i Geofizika, 46, 1: 3-20 (in Russian). 
Plates 


\section{PLATE 1}

Fig. 1a-d. Cranocephalites indistinctus Callomon, depth $117.24 \mathrm{~m} ; \mathrm{a}, \mathrm{b}-$ final fragment of the phragmocone, and the body-chamber (with its outer part cut-off during drilling), inner mould (a) and outer mould (b); c, d phragmocone, showing the ornamentation in its inner part, inner mould (c), and outer mould (d); Upper Bajocian, Indistinctus Zone; phragmocone/body-chamber boundary is arrowed; specimen no. MWG UW ZI/98/01

Fig. 2. Cranocephalites sp., depth 115.67 m; fragment of inner whorls; Upper Bajocian; specimen no. MWG UW $\mathrm{ZI} / 98 / 02$

Fig. 3. Longaeviceras ex gr. L. placenta (Leckenby) - L. longaevum (Leckenby), depth 75.22 m; Upper Callovian, Athleta Zone; specimen no. MWG UW ZI/98/05

Fig. 4. Cardioceras (Cardioceras) cordatum (Sowerby), depth $70.99 \mathrm{~m}$; Lower Oxfordian, Cordatum Zone - Cordatum Subzone; specimen no. MWG UW ZI/98/06; ×1.5

Fig. 5. Cardioceras (Plasmatoceras) tenuistriatum Borissjak, depth 70.37 m; Middle Oxfordian, Densiplicatum Zone; specimen no. MWG UW ZI/98/09; ×1.5

Fig. 6. Cardioceras (Plasmatoceras) tenuicostatum (Nikitin), depth 70.80 m; Middle Oxfordian, Densiplicatum Zone; specimen no. MWG UW ZI/98/08; ×1.5

Fig. 7. Cardioceras (Subvertebriceras) zenaidae Ilovaisky, depth $68.56 \mathrm{~m}$; Middle Oxfordian, Densiplicatum Zone; phragmocone/body-chamber boundary is arrowed; specimen no. MWG UW ZI/98/10; ×1.5

Fig. 8. Amoebites mesezhnikovi (Sykes et Surlyk), depth 62.53 m; Lower Kimmeridgian, Kitchini Zone, Subkitchini Subzone; specimen no. MWG UW ZI/98/13 

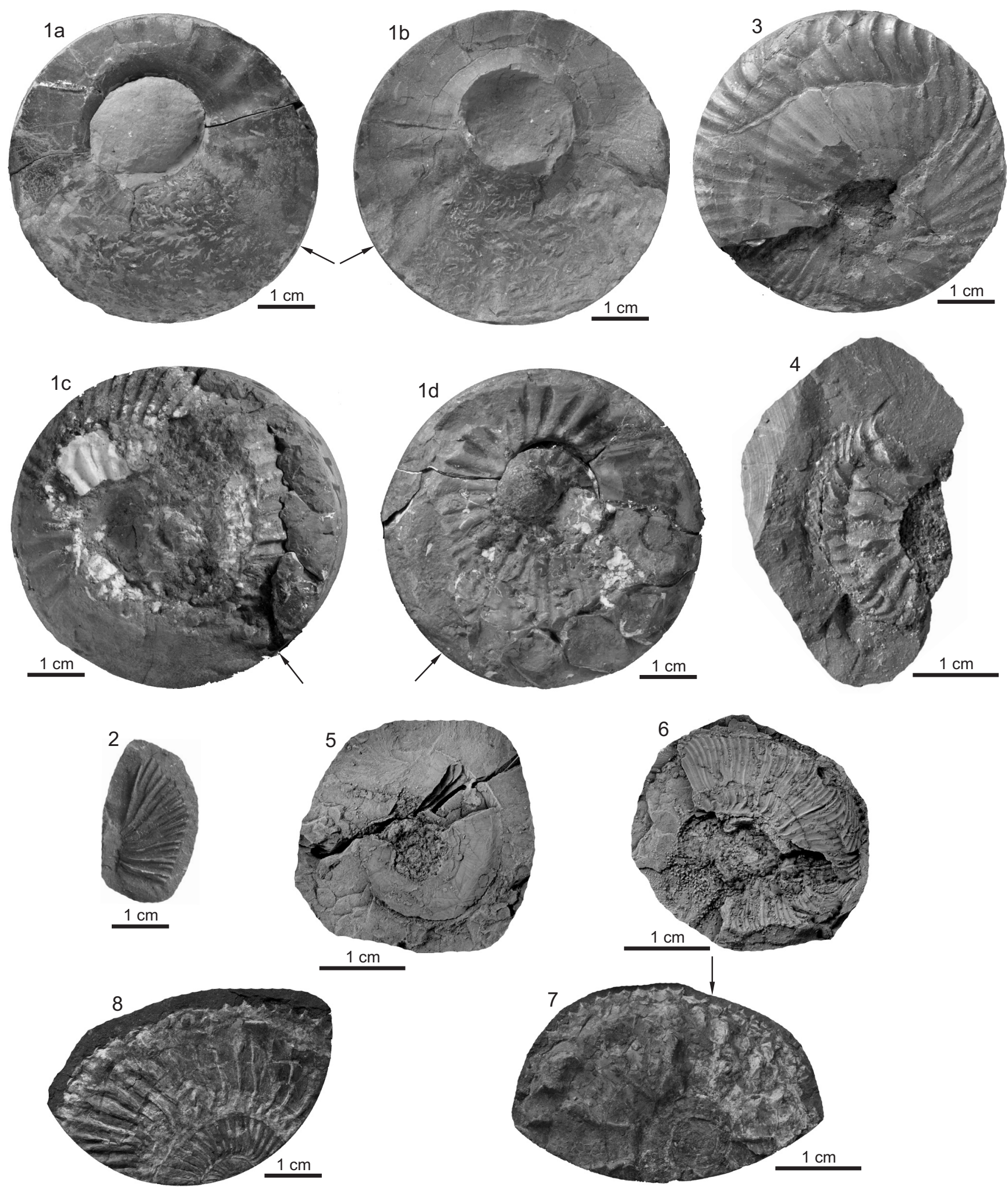

Andrzej WIERZBOWSKI, Morten SMELROR - The Bajocian to Kimmeridgian (Middle to Upper Jurassic) ammonite succession at Sentralbanken High (core 7533/3-U-1), Barents Sea, and its stratigraphical and palaeobiogeographical significance 


\section{PLATE 2}

Fig. 1. Rasenia sp., depth 61.41 m; Lower Kimmeridgian, Cymodoce Zone; specimen no. MWG UW ZI/98/15

Fig. 2. Euprionoceras cf. norvegicum (Wierzbowski), depth 60.84 m; Kimmeridgian, Kochi Zone, E. norvegicum horizon; specimen no. MWG UW ZI/98/16; ×2

Fig. 3. Zenostephanus sachsi (Mesezhnikov), depth 59.98 m; Upper Kimmeridgian, Mutabilis Zone, Mutabilis Subzone; specimen no. MWG UW ZI/98/17

Fig. 4. Zenostephanus scoticus (Arkell et Callomon), depth $58.65 \mathrm{~m}$; the phragmocone/body-chamber boundary is arrowed; Upper Kimmeridgian, Mutabilis Zone, Mutabilis Subzone; specimen no. MWG UW ZI/98/20

Fig. 5. Hoplocardioceras elegans (Spath), depth 57.66 m; Upper Kimmeridgian, Elegans Zone; specimen no. MWG UW ZI/98/21

Fig. 6. Hoplocardioceras decipiens (Spath), depth 56.83 m; Upper Kimmeridgian, Elegans Zone; specimen no. MWG UW ZI/98/24

Fig. 7. Hoplocardioceras elegans (Spath) with heavy ribbing transitional to H. decipiens (Spath), depth $54 . .84$ m; phragmocone; Upper Kimmeridgian, Elegans Zone; specimen no. MWG UW ZI/98/27

Fig. 8. Hoplocardioceras elegans (Spath), depth 48.70 m; Upper Kimmeridgian, Elegans Zone; specimen no. MWG UW ZI/98/34

All specimens in natural size unless specified otherwise 

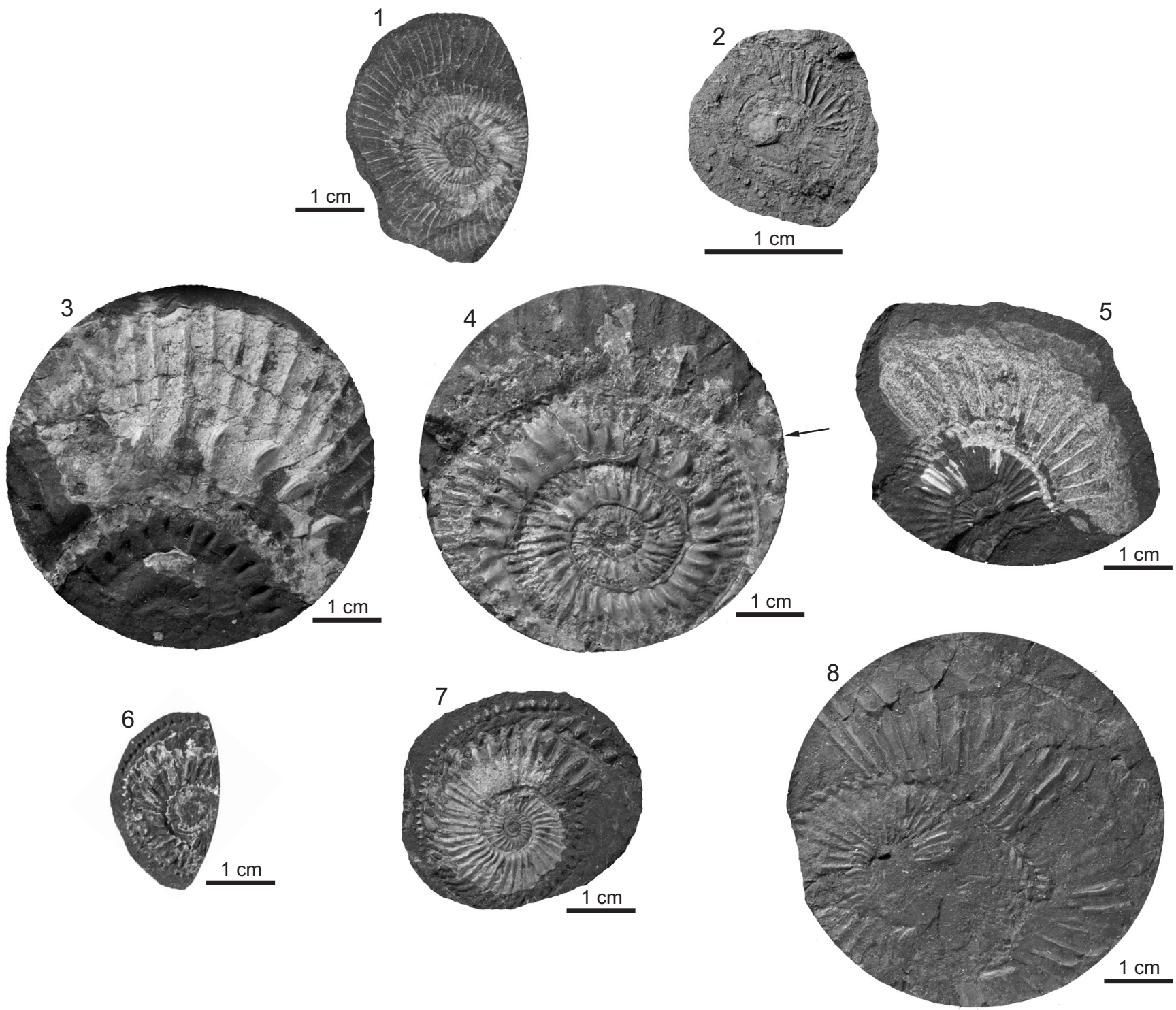

Andrzej WIERZBOWSKI, Morten SMELROR - The Bajocian to Kimmeridgian (Middle to Upper Jurassic) ammonite succession at Sentralbanken High (core 7533/3-U-1), Barents Sea, and its stratigraphical and palaeobiogeographical significance 
